\title{
Infection control practices in blood banks of Pakistan
}

Safia Bibi, ${ }^{1}$ Taranum Siddiqui, ${ }^{1}$ Syed Jafry ${ }^{2}$ and Waquaruddin Ahmed ${ }^{3}$

${ }^{1}$ PHRC Research Centre, Jinnah Postgraduate Medical Centre (JPMC), Karachi, Pakistan. ${ }^{2}$ Hussiani Blood Bank and Hussaini Thalassemia Centre,

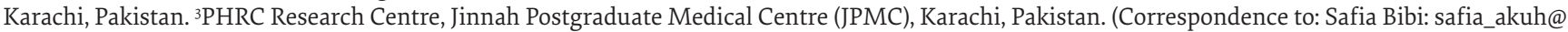
yahoo.com)

\begin{abstract}
Background: Implementation of infection control standards in blood banks is important to prevent transmission of blood-borne infections such as HIV, hepatitis B and Hepatitis C. No study from Pakistan evaluated the infection control practices in the blood banks of Pakistan.

Aims: This study aimed to evaluate infection control practices with reference to safe blood supply, staff safety and waste disposal practices in blood banks of Karachi, Pakistan.

Methods: This was a cross-sectional study. Infection control practices of all blood banks working in Karachi were determined through a structured questionnaire followed by an educational intervention. Mean scores for overall infection control practices and specific practices regarding safe blood supply, staff safety and waste disposal were calculated and compared with different factors using statistical tools.

Results: Patient safety scores of 49 (92.5\%) blood banks were within the satisfactory range but staff safety and waste disposal scores of only 26 (49.1\%) and 4 (7.5\%) blood banks were satisfactory. Significantly lower infection control (IC) scores were observed for stand-alone blood banks and those working in the absence of a haematologist $(P$-value $<0.001)$. Availability of written standard operating procedures (SOPs) and IC guidelines correlated positively $(P$-value $<0.001)$ with mean IC scores.

Conclusions: Blood banks in Karachi lack implementation of IC standards particularly with reference to staff safety and waste management and disposal. Sindh blood transfusion authority (SBTA) should take measures to increase IC compliance within blood banks.

Keywords: Blood banks; healthcare waste; hepatitis; infection control, safe blood supply,

Citation: Safia B; Siddiqui T; Jafry S; Ahmed W. Infection control practices in blood banks of Pakistan. East Mediterr Health J. 2019;25(5):331-340 https:// doi.org/10.26719/emhj.18.051

Received: 28/09/16; accepted: 13/11/17

Copyright (c) World Health Organization (WHO) 2019. Some rights reserved. This work is available under the CC BY-NC-SA 3.0 IGO license (https:// creativecommons.org/licenses/by-nc-sa/3.0/igo)
\end{abstract}

\section{Introduction}

Blood banks are an important component of the healthcare system of a country, saving lives and improving health of patients through the provision of blood. According to the World Health Organization (WHO), each year approximately 112.5 million blood donations are collected globally (1)

Blood-borne pathogens, particularly hepatitis C (HCV), hepatitis B (HBV) and HIV, are an important concern in blood banks where unsafe blood banking practices can lead to the spread of such infections (2). According to WHO the prevalence rates of $\mathrm{HCV}, \mathrm{HBV}$ and HIV collectively range from $0.02 \%, 0.03 \%, 0.003 \%$ in highincome countries to $1.03 \%, 1.08 \%$ and $3.70 \%$ respectively in low-income countries among blood donors, respectively (1). These blood donors can serve as the source of infection for blood recipients, hence screening of blood for such infections and removal of infected blood from the supply is important. Blood collected aseptically from the donor, properly screened and stored and aseptically transfused to a compatible recipient constitutes a safe blood supply.

In addition to preventing the transfusion of transmitted infections (transmission of infection to blood recipients), blood banks must also adhere to other infection control (IC) standards in order to prevent the spread of blood-borne infections. Effective policies to ensure that staff working in blood banks do not acquire infection, and to safely dispose of waste generated in a blood bank, are critical to control the spread of bloodborne infections to patients, staff and the community at large.

In Pakistan, although HIV has a relatively low prevalence, HBV and HCV are the leading causes of chronic liver disease. National sero-prevalence survey for HBV and HCV conducted by the Pakistan Medical Research Council showed an estimated 18 million individual in Pakistan infected with HBV and HCV with an overall prevalence of Hepatitis B and $C$ to be $2.5 \%$ and $4.8 \%$ respectively $(3,4)$. The risk factors identified as contributing to this endemicity were predominantly reuse of syringes and history of blood transfusion (3).

Blood banks in Pakistan are often considered a neglected component of the healthcare system. Pakistan has a highly fragmented, uncoordinated and mostly nonregulated blood transfusion service. The blood banking system in Pakistan comprises public, private or nongovernmental organization (NGO) and hospitalbased or stand-alone blood banks. This study identifies 
those aspects of the blood banking system in Pakistan that need attention by the authorities to restrict the spread of blood-borne infections to patients, healthcare workers and the community at large.

\section{Methods}

\section{Study design}

This was a cross-sectional study conducted between July 2013 and April 2014 in blood banks in Karachi, Pakistan. All operating blood banks in Karachi during the study period were included. A blood bank was excluded from the study if the director or owner of the blood bank did not consent to participate in the study.

\section{Selection of blood banks}

A list of blood banks registered with the Sindh Blood Transfusion Authority (SBTA) was obtained from SBTA's website. There was a total of 81 blood banks registered with SBTA in Karachi. Additionally, we received information (through suppliers of blood bank consumables and kits) on four blood banks that were not registered with SBTA but were operating in Karachi.

\section{Data collection instrument}

The data collection tool used in this study was adapted from that developed by the Egyptian Ministry of Health and Population (MoPH) in collaboration with Family Health International (FHI) and the United States Agency for International Development (USAID) for infection control assessment of 21 blood banks in Egypt (5). The objective of this assessment tool was to identify the circumstances and practices in blood banks that may result in transmission of blood-borne pathogens within healthcare settings including blood banks. The ultimate aim of this assessment was to reduce the transmission of bloodborne pathogens by rectifying the weaknesses identified through this tool.

The tool has two main components: the first part was based on the interview of blood bank staff while the second part was based on observation. The interview component involved interviews with three staff members from each blood bank including the director, person in charge for donations, and person in charge of the blood bank laboratory. Questions posed concerned administrative work and policies, activities related to blood donation and storage, and laboratory activities with specific emphasis on infection control. The observation component primarily included observation of blood storage, equipment monitoring, staff working, waste handling, and use of personal protective equipment etc.

\section{Data collection}

Permission or consent letters were written to the directors of all blood banks to allow the survey team to visit and interview staff. The interviewing team then visited those blood banks where directors had given consent. Overall, three personnel from each blood bank were interviewed to determine the practices of blood banks regarding IC, these included 1) blood bank manager/administrator/incharge; 2) a healthcare worker who collects blood donations; and 3) a laboratory person who performs screening. The observation part included the information on use of personal protective equipment, waste segregation practices within blood banks, use of disinfectants, monitoring of equipment and maintenance of donor records etc.

As a second component of the study, we invited staff from all blood banks in Karachi to promote awareness regarding IC practices. For this purpose a full day training seminar was organized in which three individuals from each blood bank were invited to participate. The interactive training seminar aimed to educate the participants regarding hazards associated with unsafe blood and the ways to minimize/avoid blood contamination. Results of the survey were also shared with participants in the seminar. Content covered in the seminar included donor recruitment, screening techniques in blood banks, appropriate storage of blood and blood products, infection control practices for staff safety within blood banks, and blood bank waste segregation and disposal. Facilitators of the seminar were experts regarding blood banking and infection control in Pakistan and are acknowledged in acknowledgment section. I order to record the impact of the seminar, a questionnaire was administered to the participants just before and after the seminar to record if there was any increase in the knowledge of participants after attending the seminar.

\section{Data analysis}

Data and analysis were compiled using computer package SPSS (Statistical Packages for Social Sciences) version 19.o. Results were reported in the form of frequencies and percentages for primary findings. For comparison purposes between different types of blood bank facilities, we used the scoring system in which each correct answer or appropriate practice was given a score of one, while zero score was given for each incorrect answer. As our study basically evaluated the IC practices of blood banks on the basis of three parameters: 1) practices adopted to protect staff (i.e. staff safety practices); 2) practices adopted to protect patients who will receive the blood (patient safety practices); and 3) waste handling, management and disposal practices, we therefore performed scoring for each parameter separately as well as overall scoring of all three parameters for each blood bank. A score less than $50 \%$ in any of the parameter as mentioned above was considered unsatisfactory and the blood bank in question was considered to lack implementation of IC standards in that aspect.

To find out the determinants associated with good scores for each parameter, Student's t-test and one way ANOVA (using Tukey's test for posthoc analysis) were used to show if any significant difference exists among the different blood banks operating in Karachi. As an intervention, a post-survey seminar was conducted, and pre- and post-seminar results of the test were also analyzed using paired sample t-test to determine the 
effectiveness of the seminar in conveying the appropriate knowledge regarding IC practices in blood banks.

\section{Results}

There was a total 81 registered blood banks in Karachi as per SBTA's list available online. Eleven blood banks could not be located due to lack of complete addresses available on the website, while four blood banks were recently closed by SBTA due to malpractice. Therefore, we remained with 66 registered blood banks, as well as information on four unregistered blood banks operating in the Karachi.

Of the 70 blood banks, 53 (76\%) allowed us to visit their facility; the remainder either refused to participate in the study or did not respond to our request. The total number of blood banks included in our study was 53, of which 35 $(66 \%)$ were attached to a hospital while $18(34 \%)$ operated independently or as stand-alone blood banks.

Table 1 shows the activities of blood banks surveyed and also the procedures employed for donor recruitment; here it is noteworthy that $5(8.4 \%)$ blood banks did not have any questionnaire available for the recruitment of blood donors. Blood screening tests were performed in 38 (71.7\%) blood banks; those blood banks that were not screening reported themselves as either operating as a collection point for a main blood bank, or were sending samples to a clinical laboratory for screening. Table 2 shows different screening tests and methodologies employed for blood screening; while all blood banks were performing HBV, HCV and HIV screening, syphilis and malaria testing were not performed in $3(8 \%)$ and $6(16 \%)$ blood banks respectively.

Table 3 describes the measures employed by blood banks to protect staff against any exposure to infection and waste management activities. Table 4 shows the

\begin{tabular}{|c|c|c|}
\hline Parameters & & $\begin{array}{l}\text { Number }(\%) \text { of } \\
\text { blood banks }\end{array}$ \\
\hline \multicolumn{3}{|c|}{ Basic Features of the blood bank } \\
\hline \multirow[t]{2}{*}{$\begin{array}{l}\text { Blood bank } \\
\text { premises }\end{array}$} & $\begin{array}{l}\text { Independent (stand- } \\
\text { alone) }\end{array}$ & $18(34)$ \\
\hline & Attached with hospital & $35(66)$ \\
\hline \multirow{2}{*}{$\begin{array}{l}\text { Haematologist } \\
\text { on panel }\end{array}$} & Yes & $33(62.3)$ \\
\hline & No & $20(37.7)$ \\
\hline \multirow{2}{*}{$\begin{array}{l}\text { Standard } \\
\text { operating } \\
\text { procedures }\end{array}$} & Available & $30(56.6)$ \\
\hline & Not available & $23(43.4)$ \\
\hline \multirow[t]{2}{*}{ Staff training } & On job training & $34(64.2)$ \\
\hline & $\begin{array}{l}\text { Trained and qualified } \\
\text { staff* }^{*}\end{array}$ & $19(35.8)$ \\
\hline \multirow{5}{*}{$\begin{array}{l}\text { Routine } \\
\text { activities }\end{array}$} & Donation & $52(98.1)$ \\
\hline & $\begin{array}{l}\text { Blood grouping/cross } \\
\text { matching }\end{array}$ & $53(100)$ \\
\hline & Screening & $38(71.7)$ \\
\hline & Component preparation & $27(50.9)$ \\
\hline & Transfusion & $28(52.8)$ \\
\hline \multirow{2}{*}{$\begin{array}{l}\text { Infection control } \\
\text { team }\end{array}$} & No & $39(73.6)$ \\
\hline & Yes & $14(26.4)$ \\
\hline \multicolumn{3}{|c|}{ Donor selection and recruitment criteria } \\
\hline \multirow{2}{*}{$\begin{array}{l}\text { Mobile donor } \\
\text { sessions }\end{array}$} & Yes & $20(37.7)$ \\
\hline & No & $33(62.26)$ \\
\hline \multirow[t]{2}{*}{ Donor Selection } & Voluntary only & $30(56.6)$ \\
\hline & Family replacement only & $22(43.4)$ \\
\hline \multirow{2}{*}{$\begin{array}{l}\text { Donor } \\
\text { questionnaire }\end{array}$} & Available & $48(90.6)$ \\
\hline & Not available & $5(9.4)$ \\
\hline \multirow[t]{2}{*}{ Donor Record } & Available & $48(90.6)$ \\
\hline & Not available & $5(9.4)$ \\
\hline
\end{tabular}

*Those who have a diploma (formal training) for blood banking.

\begin{tabular}{|c|c|c|c|c|c|}
\hline Parameter & Procedure & Chemiluminescence & ELISA & Rapid & Microscopy \\
\hline \multirow{2}{*}{ HBV } & Routine & $8(21.1)$ & $21(55.3)$ & $9(23.7)$ & - \\
\hline & Emergency & $8(21.1)$ & $17(44.7)$ & $13(34.2)$ & - \\
\hline \multirow{2}{*}{$\mathrm{HCV}$} & Routine & $8(21.1)$ & $21(55 \cdot 3)$ & $9(23.7)$ & - \\
\hline & Emergency & $8(21.1)$ & $17(44.7)$ & $13(34.2)$ & - \\
\hline \multirow{2}{*}{ HIV } & Routine & $8(21.1)$ & $21(55 \cdot 3)$ & $9(23.7)$ & - \\
\hline & Emergency & $8(21.1)$ & $17(44.7)$ & $13(34.2)$ & - \\
\hline \multirow{2}{*}{ Syphilis } & Routine & - & - & $35(66.0)$ & - \\
\hline & Emergency & - & - & $35(66.0)$ & - \\
\hline \multirow{2}{*}{ Malaria } & Routine & - & - & $23(43.4)$ & $9(17 \%)$ \\
\hline & Emergency & - & - & $23(43.4)$ & $9(17 \%)$ \\
\hline
\end{tabular}


Table 3. Infection control activities for Staff safety in blood banks in Karachi

\begin{tabular}{|c|c|c|}
\hline Parameters & Response & $\begin{array}{c}\text { Number }(\%) \\
(\mathbf{n}=53)\end{array}$ \\
\hline \multicolumn{3}{|l|}{ Staff safety measures } \\
\hline \multirow[t]{2}{*}{ Hepatitis B vaccination } & Yes & $18(34)$ \\
\hline & No & $35(66)$ \\
\hline \multirow[t]{2}{*}{ Gloves available } & Yes & $33(62.3)$ \\
\hline & No & $20(37.7)$ \\
\hline \multirow[t]{2}{*}{ Type of gloves } & Plastic & $30(56.6)$ \\
\hline & Latex & $23(43.4)$ \\
\hline \multirow[t]{2}{*}{ History of Needle stick injury } & Yes & $34(64.2)$ \\
\hline & & $19(35.8)$ \\
\hline \multirow{3}{*}{$\begin{array}{l}\text { *Reason for Needle stick injury } \\
(\mathrm{n}=20)\end{array}$} & Two handed recapping & $52(98.1)$ \\
\hline & Lab procedure & $53(100)$ \\
\hline & Waste handling & $38(71.7)$ \\
\hline \multirow[t]{2}{*}{ Record for needle stick/sharp injuries maintained } & Yes & $14(26.4)$ \\
\hline & No & $39(73.6)$ \\
\hline \multirow{3}{*}{$\begin{array}{l}\text { *Follow up of needle stick injuries } \\
(\mathrm{n}=20)\end{array}$} & No follow up & $11(55)$ \\
\hline & Follow but no prophylaxis & $8(40)$ \\
\hline & Follow up with prophylaxis & $1(5)$ \\
\hline \multirow[t]{2}{*}{ Reuse of glassware } & Yes & $35(66)$ \\
\hline & No & $18(34)$ \\
\hline \multirow[t]{4}{*}{ Washing of glassware } & Water only & $4(7.5)$ \\
\hline & Water and soap & $6(11.3)$ \\
\hline & Water and disinfectant & $10(18.6)$ \\
\hline & Autoclave & $5(9.4)$ \\
\hline \multirow[t]{3}{*}{ Disinfectant used for cleaning surfaces } & Water only & $6(11.3)$ \\
\hline & Sodium hypochlorite & $25(47.2)$ \\
\hline & $70 \%$ alcohol & $22(41.5)$ \\
\hline \multirow[t]{2}{*}{ Staff training on Infection control } & Yes & $19(35.8)$ \\
\hline & No & $34(64.2)$ \\
\hline \multicolumn{3}{|l|}{ Waste management and disposal } \\
\hline \multirow[t]{2}{*}{ Waste segregation } & No & $41(77.4)$ \\
\hline & Yes & $12(22.6)$ \\
\hline \multirow[t]{3}{*}{ Disposal of blood bank waste } & Disposed of as general waste & $12(22.6)$ \\
\hline & Contract with a hospital ${ }^{1}$ & $18(34)$ \\
\hline & Sent for incineration & $23(43.4)$ \\
\hline \multirow[t]{4}{*}{ Disposal of positive blood bags/ samples } & Discarded in general waste & $5(9.4)$ \\
\hline & Bag opened and emptied in sink & $3(5.7)$ \\
\hline & Buried & $4(7.5)$ \\
\hline & Sent for incineration & $41(77.4)$ \\
\hline \multirow[t]{4}{*}{ Disposal of expired blood bags } & Discarded in general waste & $7(13.2)$ \\
\hline & Bag opened and emptied in sink & $3(5.7)$ \\
\hline & Buried & $2(3.8)$ \\
\hline & Sent for incineration & $41(77.4)$ \\
\hline \multirow[t]{2}{*}{ Record of blood bags disposed off } & No & $7(13.2)$ \\
\hline & Yes & $46(86.8)$ \\
\hline \multirow[t]{2}{*}{ Disposal of waste generated during mobile sessions or camps. } & Disposed of at the site & $3(15)$ \\
\hline & & $17(85)$ \\
\hline
\end{tabular}




\begin{tabular}{|c|c|c|}
\hline Parameters & $\begin{array}{l}\text { No } \\
\text { n (\%) }\end{array}$ & $\begin{array}{l}\text { Yes } \\
\text { n (\%) }\end{array}$ \\
\hline $\begin{array}{l}\text { Sink with running water } \\
\text { available? }\end{array}$ & $3(5.6)$ & $50(94.4)$ \\
\hline Soap for hand washing available? & $5(9.4)$ & $48(90.6)$ \\
\hline Staff wearing lab coats/ uniforms? & $31(58.5)$ & $22(41.5)$ \\
\hline Staff wearing gloves? & $23(43.4)$ & $30(56.6)$ \\
\hline Gloves worn outside workplace? & $46(87)$ & $7(13)$ \\
\hline Mouth pipetting being done? & $46(87)$ & $7(13)$ \\
\hline $\begin{array}{l}\text { Disinfectant for environmental } \\
\text { cleaning available? }\end{array}$ & $6(11.3)$ & $47(88.7)$ \\
\hline $\begin{array}{l}\text { Visible blood contaminated } \\
\text { material (cotton/gauze etc.) on } \\
\text { floor }\end{array}$ & $43(81)$ & $10(18.9)$ \\
\hline $\begin{array}{l}\text { Food or drink seen in the working } \\
\text { area? }\end{array}$ & $36(68)$ & $17(32)$ \\
\hline Waste segregation being done? & $8(15.1)$ & $45(84.9)$ \\
\hline $\begin{array}{l}\text { Danger/safety box for needles/ } \\
\text { sharps available? }\end{array}$ & $34(64.2)$ & $19(35.8)$ \\
\hline $\begin{array}{l}\text { Container with disinfectant for } \\
\text { glassware available? }\end{array}$ & $35(66)$ & $18(34)$ \\
\hline $\begin{array}{l}\text { Screening results being labeled on } \\
\text { blood bags? }\end{array}$ & $6(11.3)$ & $47(88.7)$ \\
\hline
\end{tabular}

results of the observation component where activities of blood bank staff were observed with particular reference to IC. Scoring results suggested that while patient safety scores of $49(92.5 \%)$ blood banks were within the satisfactory range, staff safety and waste disposal score of only $26(49.1 \%))$ and 4 (7.5\%) blood banks were satisfactory.

Results of one way ANOVA and Post Hoc analysis for comparison of mean scores of blood banks with reference to facility type, i.e. public, private or NGO, and with reference to type of blood bank, i.e. part of a hospital or a transfusion centre or a stand-alone blood bank (only collecting donations and issuing blood for donation) is depicted in Table 5. These results suggest that the patient safety score of government-owned blood banks was significantly lower compared to NGO-run and private blood banks, while the staff safety score of standalone blood banks was significantly lower with respect to hospital-based blood banks or transfusion centres.

Analysis of factors that might contribute to the effective implementation of IC practices suggested that those blood banks supervised by a haematologist or a doctor trained in blood banking practices had a significantly higher score for staff safety as well as patient safety measures. Similarly the blood banks where written SOPs on blood banking as well as IC are available and where IC teams were working had a better score (Table 6). Here it is noteworthy that none of the parameters assessed impacted the waste management and disposal score of blood banks except the presence of written IC guidelines. Blood banks where IC guidelines were available were observed to have a significantly higher score for waste management and disposal. Paired sample t-test on pre- and post-seminar assessment suggested a significant increase ( $P$-value 0.032$)$ in overall score of attendees with reference to IC (Table 7).

\section{Discussion}

Our findings suggest that most blood banks in Karachi scored satisfactorily for safe blood supply to patients, but many lacked effective implementation of policies for staff safety and appropriate waste management and disposal. The reason behind this finding could be the fact that SBTA mostly audits and monitors blood banks for their policies regarding safe blood supply to patients; thus, blood banks prioritize adherence to those standards compared to other IC standards. However, infection control standards for staff safety and waste management and disposal are equally important, since non-compliance is a public health hazard that might contribute to the transmission of infectious agents to community.

Collection of blood from voluntary, non-remunerated and regular blood donors from low-risk populations is considered a cornerstone for blood safety. WHO and SBTA guidelines recommend the recruitment of voluntary non-remunerated blood donors with careful history and discourage paid and family replacement donations (6). It was encouraging that none of the blood banks in Karachi reported receiving paid blood donations and all blood banks either recruited voluntary donors or obtained blood as family replacement. This highlights an improvement in blood bank services in Karachi, since a previous study had reported 50\% blood banks employing paid donors (7).

Screening of blood donors using donor questionnaires was performed in $91 \%$ of blood banks. Verbal screening of donors is recommended by WHO as well as SBTPPakistan as an important IC measure to evaluate the suitability of donor for blood donation and to exclude those in the window period for transfusion transmissible infections. This also has an economic impact since many of the potentially infectious donors are excluded at this step, which saves the cost of screening tests.

Blood screening for HIV, HBV, HCV and syphilis prior to transfusion is recommended to prevent transmission of these deadly blood-borne pathogens (3). But in Pakistan, SBTP additionally recommends the screening for malaria owing to its endemicity in Pakistan (8) and reports of deaths occurring due to malarial pathogen transmitted through blood transfusion $(9,10)$. Our data suggests that while all blood banks in Karachi were screening blood for viral markers, screening for syphilis and malaria was not performed in $6(11 \%)$ and $3(6 \%)$ blood banks respectively. A recent study from Pakistan indicated a prevalence of $0.89 \%$ and $1.2 \%$ syphilis and malaria respectively in blood donors (11,12), which suggests screening blood donors for these infections is critical in order to prevent infection transmission. ELISA was the most common technique employed for screening of viral infections followed 


\begin{tabular}{|c|c|c|c|c|}
\hline \multirow[t]{2}{*}{ Independent variables } & \multicolumn{3}{|c|}{ Facility type on the basis of ownership } & \multirow[t]{2}{*}{ P-value } \\
\hline & $\begin{array}{l}\text { Public } \\
(\mathbf{n}=9)\end{array}$ & $\begin{array}{l}\text { Private } \\
(\mathbf{n}=\mathbf{2 7})\end{array}$ & $\begin{array}{l}\text { NGO } \\
(\mathbf{n}=17)\end{array}$ & \\
\hline $\begin{array}{l}\text { Staff Safety Score } \\
\text { Mean } \pm \text { SD }\end{array}$ & $7.22 \pm 2.05$ & $6.30 \pm 1.52$ & $7.35 \pm 1.90$ & 0.134 \\
\hline $\begin{array}{l}\text { Patient Safety Score } \\
\text { Mean } \pm \text { SD }\end{array}$ & $11.22 \pm 2.77$ & $13.78 \pm 2.45$ & $15.00 \pm 1.58$ & 0.001 \\
\hline $\begin{array}{l}\text { Waste Disposal Practices Score } \\
\text { Mean } \pm \text { SD }\end{array}$ & $3.00 \pm 1.80$ & $3.19 \pm 1.52$ & $4.06 \pm 1.25$ & 0.116 \\
\hline $\begin{array}{l}\text { Other Infection control related activities } \\
\text { Mean } \pm \text { SD }\end{array}$ & $3.44 \pm 1.60$ & $3.67 \pm 1.51$ & $3.82 \pm 1.82$ & 0.806 \\
\hline $\begin{array}{l}\text { Total Score } \\
\text { Mean } \pm \text { SD }\end{array}$ & $24.89 \pm 4.78$ & $26.96 \pm 5.26$ & $30.24 \pm 4.22$ & 0.022 \\
\hline \multirow[t]{2}{*}{ Independent variables } & \multicolumn{3}{|c|}{ Facility type on the basis of activities } & P-value \\
\hline & $\begin{array}{l}\text { Hospital based } \\
\quad(n=23)\end{array}$ & $\begin{array}{c}\text { Transfusion } \\
\text { Centre } \\
(\mathbf{n}=11)\end{array}$ & $\begin{array}{l}\text { Stand alone } \\
\qquad(n=19)\end{array}$ & \\
\hline $\begin{array}{l}\text { Staff Safety Score } \\
\text { Mean } \pm \text { SD }\end{array}$ & $7.17 \pm 1.59$ & $7.45 \pm 1.97$ & $6.00 \pm 1.67$ & 0.03 \\
\hline $\begin{array}{l}\text { Patient Safety Score } \\
\text { Mean } \pm \text { SD }\end{array}$ & $13.65 \pm 2.89$ & $14.82 \pm 1.60$ & $13.21 \pm 2.51$ & 0.251 \\
\hline $\begin{array}{l}\text { Waste Disposal Practices Score } \\
\text { Mean } \pm \text { SD }\end{array}$ & $3.52 \pm 1.70$ & $4.00 \pm 1.67$ & $3.00 \pm 1.11$ & 0.212 \\
\hline $\begin{array}{l}\text { Other Infection control related activities } \\
\text { Mean } \pm \text { SD }\end{array}$ & $4.00 \pm 1.58$ & $3.82 \pm 1.33$ & $3.21 \pm 1.23$ & 0.173 \\
\hline $\begin{array}{l}\text { Total Score } \\
\text { Mean } \pm \text { SD }\end{array}$ & $28.35 \pm 5.02$ & $30.09 \pm 5.30$ & $25.42 \pm 4.56$ & 0.037 \\
\hline
\end{tabular}

by rapid immuno-chromatographic test (ICT). While SBTP has recommendations for screening tests to be done before endorsing blood fit for transfusion, it does not mention which technique should be employed as minimum standard for blood screening. A recent study from India recommends ELISA technique to be used as a minimum standard for screening of blood in blood banks (13). A positive finding from our study is that more than $75 \%$ of blood banks were found to meet this minimum standard.

An IC programme in any healthcare facility has five basic components: hand hygiene, use of personal protective equipment, prevention of sharp injuries, disinfection and sterilization, and waste disposal. We surveyed all blood banks to evaluate their practices with reference to these IC components (Tables 3 and 4). It was alarming that a number of blood banks did not even have proper arrangements for hand washing such as running water and soap or disinfectant (Table 4). Use of appropriate personal protective equipment (PPE) was limited to less than $50 \%$ blood banks (Table 4). Awareness among healthcare workers (HCWs) regarding potential of exposure to infectious agents is necessary to promote use of PPEs; however, this study suggests staff in $19 \%$ of blood banks were not aware of the risk of acquiring workplace infection if appropriate IC measures were not followed. Many blood banks did not have any policy in place to record or document incidences and causes for sharp injuries or to follow up staff who had suffered such injuries (Table 3). Record keeping for such injuries is important to identify reasons for effective prevention policies.

Most common cause of sharp injuries were reported to be the two handed recapping of syringes (65\%), which again suggests lack of awareness on the part of staff regarding proper handling procedures. Staff was not vaccinated against hepatitis B in 4 (7\%) blood banks, mouth pipetting was being done in $7(13 \%)$ blood banks. All these observations suggest lack of IC standards for staff safety, which makes blood bank staff vulnerable to infections during routine work.

Safe waste management and disposal is critical to control the spread of infection (14). Blood bank activities generate a variety of clinical waste from blood contaminated cotton swabs to used syringes and blood samples which, if not disposed of properly, can lead to serious health outcomes for healthcare workers, waste handlers and the community at large (14). This study indicated poor practices regarding waste management, handling and disposal in most blood banks in Karachi. A number of blood banks even reported that all the waste generated in the blood bank is disposed as general domestic waste, which can expose the community to blood-borne infections. A recent study from Karachi reported a high prevalence of Hepatitis B, C and HIV in garbage scavengers, suggesting that inappropriate waste disposal from healthcare facilities could be a contributing factor (15). The Environment Protection Agency and the 


\section{Table 6. Comparison of Mean scores \pm SD with respect to different variables}

\begin{tabular}{|c|c|c|c|}
\hline \multirow[t]{2}{*}{ Independent variables } & \multicolumn{2}{|c|}{ Who supervises the activities of blood bank? } & \multirow[t]{2}{*}{ P-value } \\
\hline & $\begin{array}{l}\text { Doctor } \\
(\mathrm{n}=42)\end{array}$ & $\begin{array}{c}\text { Non-doctor } \\
(\mathbf{n}=\mathbf{1 1})\end{array}$ & \\
\hline $\begin{array}{l}\text { Staff Safety Score } \\
\text { Mean } \pm \text { SD }\end{array}$ & $7.24 \pm 1.65$ & $5.18 \pm 1.25$ & $<0.001$ \\
\hline $\begin{array}{l}\text { Patient Safety Score } \\
\text { Mean } \pm \text { SD }\end{array}$ & $14.17 \pm 2.41$ & $12.09 \pm 2.55$ & 0.015 \\
\hline $\begin{array}{l}\text { Waste Disposal Practices Score } \\
\text { Mean } \pm \text { SD }\end{array}$ & $3.55 \pm 1.58$ & $3.00 \pm 1.26$ & 0.294 \\
\hline $\begin{array}{l}\text { Other Infection control related activities } \\
\text { Mean } \pm \text { SD }\end{array}$ & $3.95 \pm 1.38$ & $2.64 \pm 0.81$ & 0.004 \\
\hline $\begin{array}{l}\text { Total Score } \\
\text { Mean } \pm S D\end{array}$ & $28.90 \pm 4.75$ & $22.91 \pm 3.81$ & $<0.001$ \\
\hline
\end{tabular}

\section{Independent variables}

\section{Is there any infection control team in the}

P-value

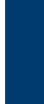

Staff Safety Score

Mean \pm SD

Patient Safety Score

Mean \pm SD

Waste Disposal Practices Score

Mean \pm SD

Other Infection control related activities

Mean \pm SD

Total Score

Mean \pm SD

\section{blood bank?}

\section{Independent variables}

\section{Written SOPs available in the blood bank?}

P-value

\section{(ntes}

Staff Safety Score

No Yes

(n=23) ( $\quad(n=30)$

Mean \pm SD

$6.30 \pm 1.64$

$7.20 \pm 1.81$

0.068

Patient Safety Score

Mean \pm SD

Waste Disposal Practices Score

Mean \pm SD

$12.43 \pm 2.74$

$14.73 \pm 1.91$

0.001

Other Infection control related activities

Mean \pm SD

Total Score

Mean \pm SD

$2.61 \pm 1.37$

$4.07 \pm 1.34$

$<0.001$

$2.52 \pm 0.66$

$4.57 \pm 1.10$

$<0.001$

$23.87 \pm 3.92$

$30.57 \pm 3.98$

$<0.001$

\section{Independent variables}

\section{IC and safety guidelines available in the blood bank? \\ $(\mathbf{n}=34)$ \\ Yes

(n=19)

Staff Safety Score

Staff Safety Score

Mean \pm SD

$6.32 \pm 1.52$

Patient Safety Score

Mean \pm SD

Waste Disposal Practices Score

Mean \pm SD

Other Infection control related activities

Mean \pm SD

Total Score

Mean \pm SD

$\begin{array}{lll}12.88 \pm 2.59 & 15.26 \pm 1.26 & 0.001 \\ 2.97 \pm 1.40 & 4.26 \pm 1.41 & 0.002 \\ 2.85 \pm 0.86 & 5.16 \pm 0.77 & <0.001 \\ 25.03 \pm 3.90 & 32.37 \pm 3.53 & <0.001\end{array}$


Table 7. Comparison of mean test scores \pm SD of participants before and after attending the seminar with respect to different variables

\begin{tabular}{lcc} 
Independent variables & \multicolumn{1}{c}{$\begin{array}{c}\text { Mean test scores } \pm \text { SD } \\
\text { After seminar } \\
\text { (n=90) }\end{array}$} \\
$\begin{array}{lc}\text { Staff Safety Questions Score } \\
\text { Mean } \pm \text { SD }\end{array}$ & $\begin{array}{c}\text { Before seminar } \\
(\mathbf{n = 9 0 )}\end{array}$ & $20.94 \pm 4.36$ \\
$\begin{array}{l}\text { Patient Safety Questions Score } \\
\text { Mean } \pm \text { SD } \\
\text { Waste Disposal Questions Score }\end{array}$ & $24.44 \pm 4.52$ & $24.78 \pm 4.29$ \\
$\begin{array}{l}\text { Mean } \pm \text { SD } \\
\text { Total Score } \\
\text { Mean } \pm \text { SD }\end{array}$ & $32.44 \pm 4.63$ & $32.00 \pm 5.34$ \\
\hline${ }^{*}$ For those who reported history of needle stick injury. & $76.94 \pm 8.37$ & $78.17 \pm 7.84$ \\
\hline
\end{tabular}

Ministry of Environment in Pakistan developed hospital waste management rules in 2005; however, these rules do not specifically address blood banks (16). SBTP in the National Blood Policy and Strategic Framework (2008-2012) for blood transfusion services set the goal of developing national guidelines for safe disposal of infectious waste from blood banks, but unfortunately the guidelines have not yet been developed.

Comparative analysis of blood banks on the basis of mean scores suggested that the patient safety score of government-run blood banks was significantly lower compared to private and NGO-based blood banks. In Karachi, the government does not have any stand-alone blood banks, and are in fact usually working within a government hospital. As per our observation, while some blood banks in government hospitals were doing a remarkable job, unfortunately in many hospitals appropriate IC standards for screening and storage of blood bags were not being followed, and there was no concept of culturing random samples to check bacterial contamination of stored blood, which contributed to their lower scores. Similarly, stand-alone blood banks were found to have significantly lower scores for staff safety. In addition, these facilities scored low in terms of patient safety, but it was not found to be statistically significant $(P$-value $=0.251)$. This could be explained by the fact that hospitals and transfusion centres manage patients within their facility and are therefore more concerned about the patient as well as staff safety and have comparatively stringent IC policies.

Furthermore, the comparative analysis of factors effecting mean scores of different IC parameters suggest that the presence of a qualified doctor trained in haematology significantly increases patient safety and staff safety scores in blood banks. WHO also recommends that blood transfusion services have a medical director with specialized training in blood transfusion (6), and our findings would endorse this recommendation. Presently only $33(62.3 \%)$ blood banks were supervised by a qualified haematologist while the healthcare staff in 10 (18.9\%) blood banks comprised solely technicians. A previous study conducted in 2000 had reported that $54 \%$ of blood banks in Karachi did not have any doctor with specialized training on blood transfusion (6). Presence of written SOPs on blood banking as well as IC was found to significantly affect the mean IC scores of blood banks. Only $14(26.4 \%)$ blood banks in Karachi had an IC team or a person allocated for IC, while HCWs from 34 (64.2\%) blood banks reported that they had no training on the topic. These findings suggests that SBTA must design a policy that compels blood banks to have a haematologist for supervising the blood bank and advising blood banks to develop their SOPs and IC guidelines for implementation of Infection control standards.

This study had limitations. Although we carried out an intervention in terms of educating blood bank managers and staff regarding IC standards in blood banks, which resulted in a significant increase in knowledge score of attendees, we could not conduct a post-intervention survey to assess the impact of this intervention on implementation of IC standards. This was due to limited resources and time constrains.

Our study suggests that current practices in blood banks in Karachi depart from IC standards, particularly with reference to staff safety and waste management or disposal. On the basis of these results we recommend that policy-makers and authorities give due consideration to the weaknesses identified in this study. Continuous monitoring and auditing of blood banks to evaluate their practices can help authorities to implement standards. Due consideration must be given to the regular training of blood bank staff. IC guidelines (including waste management and disposal) must be designed and shared with blood banks in order to facilitate the adoption of standard IC procedures to protect donors, patients, blood bank staff and the community at large.

Funding: Pakistan Health Research Council.

Competing interests: None declared. 


\section{Pratiques de lutte contre les infections dans les banques de sang du Pakistan \\ Résumé}

Contexte : La mise en œuvre de normes de lutte anti-infectieuse dans les banques de sang est importante pour prévenir la transmission d'infections transmises par le sang telles que le VIH, l'hépatite B et C. Aucune étude au Pakistan n'a évalué les pratiques dans ce domaine dans les banques de sang du pays.

Objectifs : La présente étude visait à évaluer les pratiques de lutte anti-infectieuse eu égard à la sécurité des approvisionnements en sang, la sécurité du personnel et l'élimination des déchets dans les banques de sang de Karachi au Pakistan.

Méthodes : Il s'agissait d'une étude transversale. Les pratiques de lutte contre les infections de toutes les banques de sang en exploitation à Karachi ont été déterminées au moyen d'un questionnaire structuré suivi d'une intervention éducative. Les scores moyens pour l'ensemble des pratiques de lutte contre les infections et les pratiques spécifiques concernant la sécurité des approvisionnements en sang, la sécurité du personnel et l'élimination des déchets ont été calculés et comparés à différents facteurs au moyen d'outils statistiques.

Résultats : Les scores de sécurité des patients de 49 (92,5\%) banques de sang se situaient dans la plage satisfaisante, mais les scores concernant la sécurité du personnel et l'élimination des déchets de seulement $26(49,1 \%)$ et 4 (7,5\%) banques de sang étaient satisfaisantes. Des scores significativement plus faibles en ce qui concerne la lutte contre les infections ont été observés pour les banques de sang autonomes et celles qui fonctionnent en l'absence d'un hématologue (valeur $p<0,001)$. La disponibilité de modes opératoires normalisés écrits et de lignes directrices sur la lutte contre les infections était corrélée positivement (valeur $p<0,001$ ) avec les scores moyens de lutte contre les infections.

Conclusions : Les banques de sang de Karachi n'appliquent pas les normes de lutte contre les infections, notamment en ce qui concerne la sécurité du personnel et la gestion et l'élimination des déchets. L'organisme responsable des transfusions sanguines de la province de Sind devrait prendre des mesures pour accroître la conformité à la lutte contre les infections au sein des banques de sang.

$$
\text { صمارسات مكافحة العدوى في بنوك، ترنم صديقي، سيد جعفري، وقار الدين في باكستان }
$$

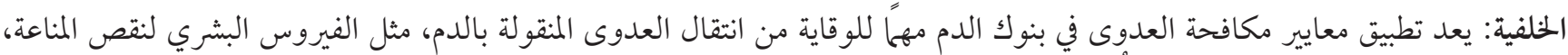

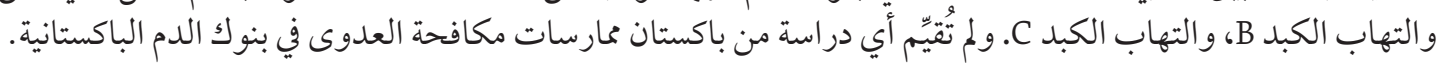

$$
\begin{aligned}
& \text { الأهداف: هدفت هذه الدراسة إلى تقييم ممارسات مكافحة العدوى من حيث إمدادات الدم المأمون، وسلامة العاملين، وممارسات التخلص من }
\end{aligned}
$$

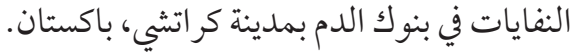

$$
\begin{aligned}
& \text { طرق البحث: تعد هذه الدراسة دراسة مقطعية. وتم تحديد متارسات مكافحة العدوى في جميع بنوك الدم العاملة في مدينة كراتشي من خلال }
\end{aligned}
$$

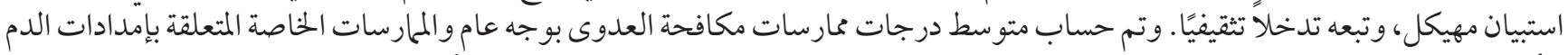

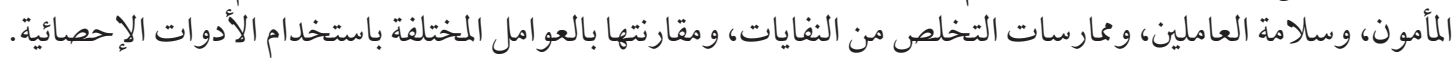

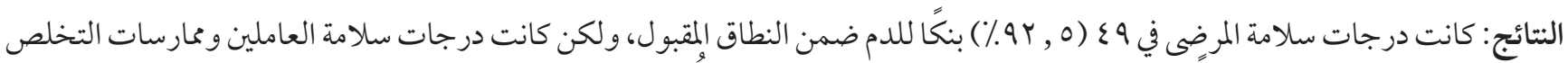

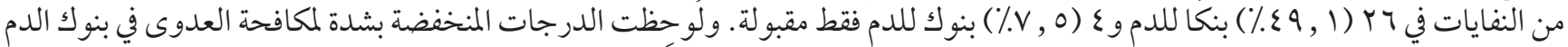

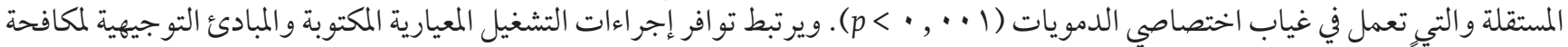

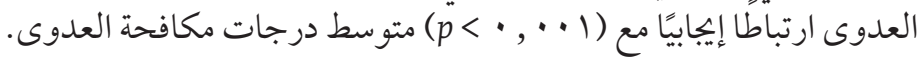

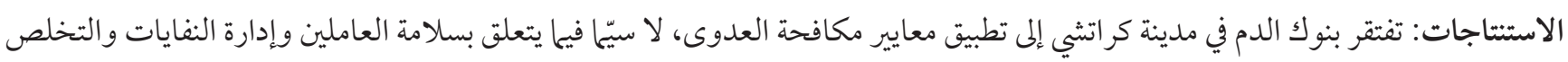

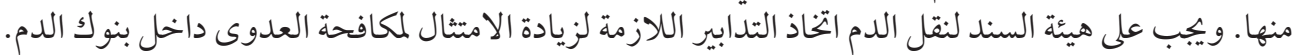

\section{References}

1. World Health Organization. Blood safety and availability. Fact Sheet. Geneva: World Health Organization; 2017 (http://www. who.int/mediacentre/factsheets/fs279/en/)

2. World Health Organizations. Screening donated blood for transfusion transmitted infections. Recommendations. Geneva: World Health Organization; 2010.

3. Prevalence of Hepatitis B and C in Pakistan. Pakistan Medical Research Council. PMRC; 2009. 
4. Qureshi H, Bile KM, Jooma R, Alam SE, Afridi HUR. Prevalence of hepatitis B and C viral infections in Pakistan: findings of a national survey appealing for effective prevention and control measures. East Mediterr Health J. 2010;16 Supp.:S15-23. http:// dx.doi.org/10.26719/2010.16.Supp.15

5. Ministry of Health and Population (MoHP). Infection control practices assessment tool for blood banks. Cairo: MoHP; 2004 (https://www.fhi36o.org/resource/infection-control-assessment-tool-blood-banks).

6. Gibbs WN, Britten AFH. Guidelines for the organization of a blood transfusion service. Geneva: World Health Organization; 1992.

7. Luby S, Zia M, Vellani Z, Ali M, Qureshi AH, Khan AJ, et al. Evaluation of blood bank practices in Karachi, Pakistan and the government's response. Health Policy Plan. 2000;15(2):217-22. http://dx.doi.org/10.1093/heapol/15.2.217

8. Diop S, Nadiaye M, Seck M, Chevalier B, Jambou R, Sarr A, et al. Prévention du paludisme post-transfusionnel en zone d'endémie. Transfus Clin Biol. 2009;16:454-9. http://dx.doi.org/10.1016/j.tracli.2009.02.004

9. Jawad F. Sarwar Jahan Zuberi (Orbituary). J Pak Med Assoc. 2004;54:167.

10. Rehman M, Jawaid SA. Need for a national blood policy to ensure safe blood transfusion. Pak J Med Sci. 2004;20(2):81-4.

11. Ali N, Ahmed J, Ali N, Jehan F, Saleem S. Trnsfusion transmitted malaria in three major blood banks of Peshawar, Pakistan. Afr J Biotechnol. 2010;9:5445-9.

12. Waheed U, Khan H, Satti HS, Ansari MA, Malik MA, Zaheer HA. Prevalence of transfusion transmitted infections among blood donors of a teaching hospital in Islamabad. Ann Pak Int Med Sci. 2012;8:236-9.

13. Maity S, Nandi S, Biswas S, Sadhukhan SK, Saha MK. Performance and diagnostic usefulness of commercially available Enzyme Linked Immunosorbent Assay and rapid kits for detection of HBV, HCV and HIV in India. Virol J. 2012;9(1):290. http://dx.doi. org/10.1186/1743-422X-9-290

14. Nwachukwu NC, Orji FA,Ugbogu OC. Health care waste management - Public health benefits and the need for effective environmental regulatory surveillance in Federal Republic of Nigeria. In: Rodriguez-Morales AJ (editor). Current Topics in Public health. IntechOpen; 2013. http://dx.doi.org/10.5772/53196.

15. Rauf MU, Saleem MD, Anwer MO, Ahmed G, Aziz S, Memon MA. HIV, hepatitis B and hepatitis C in garbage scavengers of Karachi. J Pak Med Assoc. 2013;63:798-802.

16. Ministry of Environment. The Hospital Waste Management Rules, 2005. Islamabad: Ministry of Environment; 2005 (https:// www.elaw.org/system/files/rHWMRules2005.pdf). 